Editorial

\title{
Biópsia de medula óssea e sua interpretação - o papel do hematopatologista
}

Bone marrow biopsy - the role of the hematopathologist

Patricia M. Cury

A biópsia de medula óssea (BMO) é um procedimento amplamente utilizado na prática médica, não só para o diagnóstico de diversas doenças hematológicas ou metastáticas mas também no acompanhamento das primeiras. ${ }^{1}$

Desde o início do século passado, alguns pesquisadores tentaram obter fragmentos de medula óssea com o intuito de estudar o tecido medular. ${ }^{2}$ Entretanto, Arinkin, em 1929, foi o primeiro a utilizar o método da punção aspirativa da medula óssea para o estudo citológico sistemático, propiciando o reconhecimento e descrição das células precursoras. Em 1958, Macfarland descreveu as vantagens da retirada de um fragmento ósseo, utilizando a agulha de Silverman. Com esse método, obtinha-se uma maior quantidade de material medular, o que possibilitava um maior número de cortes e de colorações histológicas. Já Jamshidi introduziu uma nova agulha de BMO, em 1971, a qual apresentava a vantagem de ser menos traumática e mais confortável ao manuseio, conseguindo boa quantidade de material medular, além de preservar melhor o fragmento. A agulha original de Jamshidi foi modificada por Inwood alguns anos após, o qual conseguiu melhorias da obtenção do material celular. Desde então, existem inúmeras agulhas para uso clínico, de diversas procedências.
Embora o mielograma (punção aspirativa) seja um procedimento mais simples e confortável do que a BMO, esta última acaba fornecendo dados importantes de maneira melhor que a citologia, como, por exemplo, o grau de celularidade medular e o diagnóstico de mielofibrose e mieloesclerose. Nos linfomas, a natureza focal de algumas lesões faz com que, freqüentemente, as agulhas de punção não sejam eficazes. Outro exemplo seria o uso da BMO no transplante de medula óssea, procedimento essencial para o seguimento desses pacientes. Atualmente, a BMO tem indicação no diagnóstico de aplasia medular, das síndromes mieloproliferativas, dos linfomas, do mieloma múltiplo, dos carcinomas metastáticos, das doenças de depósito e inclusive de doenças infecciosas. ${ }^{1}$

Praticamente não existe contra-indicação para a realização da $\mathrm{BMO}$, sendo esse procedimento realizado inclusive em portadores de doenças hemorrágicas sem observação de maiores danos. ${ }^{3}$

O diagnóstico através de uma BMO, portanto, é de vital importância clínica. Por conseqüência, o hematopatologista tem um papel fundamental. Além da avaliação morfológica das diversas linhagens celulares existentes na medula, este especialista tem que ter um conhecimento profundo dos métodos complementares de diagnóstico, principalmente dos inúmeros marcadores imunofenotípicos. Estes marcadores vão contribuir não só na determinação da

Chefe do Departamento de Patologia e Medicina Legal da Faculdade de Medicina de São José do Rio Preto - FAMERP.

Correspondência para: Dra. Patrícia Maluf Cury

Av. Brigadeiro Faria Lima, 5416

15090-000 - São José do Rio Preto -SP

E-mail: pmcury@famerp.br 
linhagem celular como também na subpopulação e no estágio de diferenciação da população linfóide envolvida em uma doença linfoproliferativa, por exemplo.

A correta interpretação dos nódulos linfóides, como mencionada no artigo desse número por Magalhães e colaboradores, é um exemplo das dificuldades de diagnóstico que o hematopatologista enfrenta. Os nódulos linfóides podem ser confundidos pelo patologista menos experiente como infiltração neoplásica, o que mudaria completamente a conduta. ${ }^{4}$ Por isso tudo, a experiência do hematopatologista, associada a métodos complementares, é fundamental para o diagnóstico correto de uma BMO. 5,6

\section{Referências bibliográficas}

1. Diebold J, Molina T, Camilleri-Broet S, Tourneau A, Audin $\mathrm{J}$. Bone marrow manifestations of infections and systemic diseases observed in bone marrow trephine biopsy. Histopathology 2000;37:199-211.

2. Wintrobe MM, Lee G, Boggs RG et al. Clinical Hematology. Lea \& Febiger, Philadelphia. $8^{\text {th }}$ edition 1981.

3. Hernandez Nieto L, Rozman C. Biópsia medular en la clinica hematologica. Salvat Editores SA, BarcelonaEspanha, 1980.

4. Thiele J, Zirbes TK, Kvasnicka HM, Fisher R. Focal lymphoid aggregates (nodules) in bone marrow biopsies: differentiation between benign hyperplasia and malignant lymphoma - a pratical guideline. J Clin Pathol 1999;52:294-300.

5. Knowles DM. Immunophenotypic and immunogenotypic approaches useful in distinguishing benign and malignant lymphoid proliferations. Sem Oncol 1993; 20:583-610.

6. Maes B, Achten R, Demunter A, Peeters B, Verhoef G, De Wolf Peeters C. Evaluation of B cell lymphoid infiltrates in bone marrow biopsies by morphology, immunohistochemistry and molecular analysis. J Clin Pathol 2000;53:835-40.

Recebido: $15 / 06 / 03$

Aceito: 27/06/03 